MISES: Revista Interdisciplinar de Filosofia, Direito e Economia

ISSN 2318-0811

Volume II, Número 2 (Edição 4) Julho-Dezembro 2014: 481-489

\title{
As Implicações Sociais e Políticas da Burocratização*
}

\author{
Ludwig von Mises ${ }^{* *}$
}

\begin{abstract}
Resumo: Este texto trata de algumas implicações mais amplas da expansão do setor público e da gestão burocrática que a acompanha, como os conflitos entre os interesses dos funcionários e os dos cidadãos, a influência da burocratização na atividade acadêmica e as contradições entre objetivos de diferentes setores da administração púbica. É de especial interesse notar o uso da hipótese de funcionários auto interessados na análise, antecipando a tradição da escola da escolha pública.
\end{abstract}

Palavras-chave: Burocracia, Setor Público, Gestão Burocrática

\section{The Social and Political Implications of Bureaucratization}

\begin{abstract}
This text addresses some wider implications of the expansion of the public sector and bureaucratic management that accompanies it, such as the conflict between the interests of employees and citizens, the influence of bureaucracy in the academic activity and the contradictions between goals of different areas of public administration. It is of particular interest the use of the hypothesis of self-interested public servants in the analysis, which anticipates the public choice tradition.
\end{abstract}

Keywords: Bureaucracy, Public Sector, Bureaucratic Management

Classificação JEL: D73, H1

\footnotetext{
* Texto publicado pela primeira vez em inglês no ano de 1944 como quinto capítulo do livro Bureaucracy. A presente tradução foi feita a partir da seguinte edição: MISES, Ludwig von. The Social and Political Implications of Bureaucratization. In: Bureaucracy. New Haven: Yale University Press, 1944. p. 74-92.

Traduzido do original em inglês para o português por Heloisa Gonçalves Barbosa

${ }^{* *}$ Ludwig von Mises nasceu em 29 de setembro de 1881 na cidade de Lviv, atualmente na Ucrânia e na época parte do território do Império Austro-Húngaro. Estudou, a partir de 1900, na Universidade de Viena, e recebeu o título de Doutor em Direito por essa mesma instituição em 1906. Lecionou na Universidade de Viena de 1913 a 1934, no Instituto Universitário de Altos Estudos Internacionais em Genebra de 1934 a 1940 e na New York University de 1945 a 1969. É autor de centenas de artigos acadêmicos e de mais de vinte livros dentre os quais se destaca o tratado de economia Ação Humana (Instituto Ludwig von Mises Brasil, 2010). Faleceu no dia 10 de outubro de 1973 em Nova York, nos Estados Unidos.
} 


\section{I - A Filosofia do Burocratismo}

Era simples o antagonismo com que o povo se defrontava nas antigas batalhas em prol da liberdade, e todos eram capazes de compreendê-lo. De um lado, havia os tiranos e seus partidários; do outro, estavam os defensores do governo popular. Os conflitos políticos consistiam na disputa entre diversos grupos pela conquista da supremacia. A pergunta era: Quem deve governar? Nós ou eles? Os poucos ou os muitos? O déspota, a aristocracia ou o povo?

Hoje, a estatolatria, a filosofia da moda, vem obscurecendo a questão. Não mais se percebem os conflitos políticos como lutas entre grupos de homens, mas são considerados uma guerra entre dois princípios, entre $\mathrm{o}$ bem e o mal. O bem personifica-se no grande deus Estado, a materialização da eterna ideia da moralidade, e o mal, no "individualismo robusto" de homens egoístas ${ }^{1}$ Neste antagonismo, o Estado tem sempre razão e o indivíduo está sempre errado. O Estado representa o bem comum, a justiça, a civilização e uma sabedoria superior. $\mathrm{O}$ indivíduo é um miserável, um idiota maléfico.

Quando um alemão se refere a "der Staat" (o Estado) ou quando um marxista menciona "a sociedade", são dominados por um respeito cheio de reverência. Como pode um homem ser tão inteiramente corrupto que ouse rebelar-se contra este Ser Supremo?

Luís XIV (1638-1715) foi muito franco e sincero quando disse: "L'Étatc'est moi" (Eu sou o Estado); já o estadista moderno prima pela modéstia. Diz: sou servo do Estado, mas está aí implícito que o Estado é Deus. É possível revoltar-se contra um rei Bourbon, como o fizeram os franceses. Naturalmente, tratavase de uma luta de homens contra homens. No entanto, não é possível revoltar-se contra o

\footnotetext{
${ }^{1}$ Esta é a interpretação política da questão. Para a atual interpretação econômica, ver: MISES, Ludwig von. Is There any Remedy Available? Bureaucracy. New Haven: Yale University Press, 1944. p. 109-21. Esp. p. 117-19.
}

deus Estado e contra seu humilde faz-tudo, o burocrata.

Não questionemos a sinceridade do funcionário público bem-intencionado. Está ele totalmente imbuído da ideia de que é seu dever sagrado lutar por seu ídolo contra o egoísmo do populacho. Em sua opinião, vê-se como o verdadeiro paladino da eterna lei divina. Não se sente moralmente obrigado pelas leis humanas que os defensores do individualismo inscreveram nos estatutos. Os homens não podem alterar as verdadeiras leis de seu deus, o Estado. O cidadão, ao transgredir uma das leis de seu país, torna-se um criminoso merecedor de castigo: agiu em proveito próprio, de forma egoísta. Porém, é bem diversa a situação quando um funcionário público infringe as leis devidamente promulgadas da nação para o bem do "Estado". Na opinião dos tribunais "reacionários", o funcionário pode ser tecnicamente culpado por uma contravenção. Contudo, em um sentido moral mais elevado, agiu de maneira correta. O funcionário infringe as leis humanas para não violar a lei divina.

Esta é a essência da filosofia do burocratismo. As leis escritas são, aos olhos dos funcionários públicos, barreiras erguidas para a proteção dos canalhas contra as justas reivindicações da sociedade. Por que deveria um criminoso escapar da punição só porque, ao processá-lo, o "Estado", violou algumas banais formalidades? Por que deveria um indivíduo pagar menos impostos só porque a legislação tributária contém uma falha? Por que deveriam os advogados ganhar a vida aconselhando as pessoas sobre como lucrar com as imperfeições da lei escrita? De que valem todas as restrições impostas pela lei escrita sobre os honestos esforços do funcionário do governo para dar felicidade ao povo? Se, ao menos, não houvesse constituições, declarações de direitos, leis, parlamentos e tribunais! Jornais e advogados! Como seria bom o mundo se o "Estado" fosse livre para sanar todos os males!

O totalitarismo perfeito de Josef Stalin (1878-1956) e Adolf Hitler (1889-1945) está a apenas um passo dessa mentalidade. 
É óbvia a resposta a ser dada a esses burocratas radicais. Cabeaocidadãoredarguir: vocês podem ser excelentes e nobres homens, muito melhores do que os demais cidadãos. Não questionamos sua competência nem sua inteligência. Mas vocês não são os vigários de um deus denominado "Estado". São servos da lei, das leis devidamente aprovadas por nossa nação. Não é seu papel criticar a lei, e, menos ainda, infringi-la. Ao violar a lei, talvez estejam agindo de modo pior do que boa parte dos trapaceiros, não importa que sejam boas suas intenções. Pois foram nomeados, empossados e são pagos para fazer cumprir a lei, não para transgredi-la. A pior lei é melhor do que a tirania burocrática.

A principal diferença entre um policial e um sequestrador e entre um coletor de impostos e um ladrão é que o policial e o cobrador de impostos cumprem e fazem cumprir a lei, enquanto o sequestrador e o assaltante violam-na. Removendo-se as leis, a sociedade será destruída pela anarquia. $\mathrm{O}$ Estado é a única instituição que tem o direito de aplicar coerção e coação e de infligir danos aos indivíduos. Não é possível relegar este enorme poder ao arbítrio de alguns homens, por mais competentes e inteligentes que se suponham. É necessário limitar a aplicação desse poder: esta é a missão das leis.

Os funcionários públicos e os burocratas não são o Estado. São indivíduos selecionados para a aplicação das leis. Podem-se qualificar esta opinião como ortodoxa e doutrinária, pois, de fato, expressa antigas sabedorias. Contudo, a alternativa para o Estado de Direito é o domínio do déspota.

\section{II - A Complacência Burocrática}

A tarefa do funcionário público é servir ao público. Seu cargo foi criado - direta ou indiretamente - por um ato legislativo e pela alocação orçamentária dos meios necessários a sua manutenção. $\mathrm{O}$ funcionário executa as leis de seu país. No desempenho das suas funções, demonstra ser um membro útil da comunidade, mesmo quando as leis que deve colocar em prática forem prejudiciais ao bem comum, pois não é ele o responsável por sua inadequação. A culpa é do povo soberano, não do executor fiel da vontade do povo. Assim como os destiladores não são responsáveis pelo fato de as pessoas se embriagarem, da mesma forma, os funcionários do governo não são responsáveis pelas consequências indesejáveis de leis insensatas.

Por outro lado, não é por mérito dos burocratas que suas ações têm como resultado grandes benefícios. $\mathrm{O}$ fato de o trabalho do departamento de polícia ser tão eficiente que os cidadãos sejam razoavelmente bem protegidos contra assassinatos, roubos $\mathrm{e}$ furtos não obriga o restante do povo a ser mais grato aos policiais do que a quaisquer outros concidadãos que prestam serviços úteis. O oficial de polícia e o bombeiro não têm mais direito à gratidão do público do que os médicos, os maquinistas da ferrovia, os soldadores, os marinheiros ou os fabricantes de qualquer produto útil. $O$ guarda de trânsito não tem mais motivo de orgulho do que o fabricante de sinais de trânsito. Não é mérito seu que seus superiores tenham-lhe atribuído um dever em que dia a dia e hora a hora o guarda impede mortes acidentais e assim, salva muitas vidas.

É fato que a sociedade não poderia dispensar os serviços prestados por policiais, coletores de impostos e oficiais de justiça. Porém, não é menos verdade que todos sofreriam grandes prejuízos se não houvesse catadores de papel, limpadores de chaminé, lavadores de pratos e exterminadores de insetos. No âmbito da cooperação social, todo cidadão depende dos serviços prestados por todos os seus concidadãos. O grande cirurgião e o músico eminente jamais poderiam concentrar todos os seus esforços na cirurgia ou na música se a divisão do trabalho não os houvesse libertado da necessidade de cuidar de diversas minúcias cuja realização os teria impedido de se tornarem consumados especialistas. $\mathrm{O}$ embaixador e o faroleiro 
não têm mais direito ao epíteto de pilares da sociedade do que o cabineiro ferroviário ou a faxineira. Pois, dentro da divisão do trabalho, a estrutura da sociedade repousa sobre os ombros de todos os homens e mulheres.

Há, é claro, homens e mulheres que servem de maneira altruísta e totalmente desinteressada. A humanidade nunca teria alcançado seu estado atual de civilização sem o heroísmo e a abnegação de uma elite. Cada passo à frente no caminho em direção a um aperfeiçoamento das condições morais foi uma conquista de indivíduos que estavam dispostos a sacrificar seu próprio bem-estar, sua saúde e suas vidas em prol de uma causa que consideravam justa e benéfica. Fizeram o que consideravam seu dever sem se preocupar em serem vitimados eles mesmos. Essas pessoas não agiram em busca de uma recompensa, mas serviram sua causa até a morte.

Foi uma confusão proposital por parte dos metafísicos alemães da estatolatria o fato de paramentarem todos os indivíduos a serviço do governo com a auréola desse autossacrifício altruísta. A partir dos escritos dos estatistas alemães, o funcionário público emerge como um ser santificado, uma espécie de monge que abandonou todos os prazeres terrenos e toda a felicidade pessoal a fim de servir, dando o máximo de sua capacidade, ao lugar-tenente de Deus, outrora o rei Hohenzollern, hoje, o Führer. O Staatsbeamte (funcionário público) não trabalha pelo salário, porque salário nenhum, por maior que seja, poderia ser considerado uma recompensa adequada pelos benefícios inestimáveis e de valor incalculável que a sociedade recebe por meio de seu abnegado sacrifício. A sociedade lhe deve não um salário, mas uma manutenção adequada a seu nível na hierarquia oficial. É um equívoco chamar de salário a esta manutenção ${ }^{2}$. Somente os liberais, induzidos pelos preconceitos e erros do comercialismo, utilizam termo tão equivocado. Se o Beamtengehalt (salário do servidor público) fosse um

\footnotetext{
${ }^{2}$ Ver: LABAND, Paul. Das Staatsrecht des Deutschen
} Reiches. Tübingen: Mohr, $5^{\mathfrak{a}}$ ed., 1911. Vol. I, p. 500. verdadeiro salário, seria apenas justo e natural facultar ao titular do cargo mais modesto uma renda maior do que a de qualquer indivíduo fora da hierarquia oficial. Quando em serviço, todo servidor público é um mandatário da soberania e da infalibilidade do Estado. Seu testemunho no tribunal vale mais do que o do leigo.

Tudo isso é rematada tolice. Em todos os países, a maioria das pessoas quis integrar o pessoal das repartições públicas porque o salário e a pensão oferecidos eram mais elevados do que os que poderiam vir a obter em outras ocupações. A nada renunciaram ao servir ao governo. Para eles, o serviço público era o emprego mais rentável que podiam encontrar.

Os incentivos oferecidos ao serviço público na Europa não consistiam apenas no nível do salário e na pensão; muitos candidatos, e não os melhores, foram atraídos pela facilidade do trabalho e pela segurança. De maneira geral, os empregos no governo eram menos exigentes do que os do mundo dos negócios. Além disso, as nomeações eram vitalícias. O funcionário só pode ser demitido quando um tipo de julgamento judicial o considera culpado de hedionda negligência das suas funções. Na Alemanha, Rússia e França, todos os anos muitos milhares de meninos, cujos planos de vida eram completamente fixos e previsíveis, entravam no nível inicial do ensino secundário. Iriam obter seus diplomas, iriam conseguir um emprego em uma das muitas repartições, trabalhariam trinta ou quarenta anos e, então, se aposentariam com uma pensão. Para eles, a vida não tinha surpresas ou emoções, tudo era simples e conhecido de antemão.

Um exemplo ilustra bem a diferença entre o prestígio social dos empregos públicos na Europa continental e nos Estados Unidos. Na Europa, a discriminação social e política contra um grupo minoritário tomou a forma de barrar essas pessoas do acesso a todos os cargos no governo, mesmo os mais cargos mais modestos e menor salário. $\mathrm{Na}$ Alemanha, no Império Austro-Húngaro, 
como em muitos outros países, todos os empregos subordinados que não exigem habilidades ou formação especiais - tais como atendentes, porteiros, lanterninhas, bedéis, meirinhos, mensageiros, zeladores - foram reservados por lei para ex-soldados que voluntariamente prestaram mais anos de serviço ativo nas forças armadas do que o mínimo exigido por lei. Esses empregos eram tidos como recompensas de grande valor para os suboficiais. Aos olhos do povo, era um privilégio servir como atendente em uma repartição pública. Se, na Alemanha, houvesse uma classe com o status social do negro norte-americano, essas pessoas jamais se aventurariam a candidatar-se a um desses postos de trabalho. Teriam consciência de que tal ambição era excessiva para eles.

\section{III - O BurocratA COMO ElEITOR}

O burocrata não é apenas um empregado dogoverno: sob uma constituição democrática, é, ao mesmo tempo, um eleitor e, como tal, uma parte do soberano, seu empregador. É singular a posição que ocupa: é, ao mesmo tempo, o empregado e o empregador. Além disso, na qualidade de empregado, seu interesse pecuniário predomina sobre seu interesse como empregador, na medida em que recebe muito mais dos fundos públicos do que contribui para eles.

Maior relevância adquire esta dupla relação à medida que aumenta o número de pessoas na folha de pagamento do governo. Como eleitor, o burocrata anseia mais por conseguir um aumento do que por manter o equilíbrio orçamentário. Sua principal preocupação é inchar a folha de pagamento.

Nosanosqueimediatamente precederam a queda de suas constituições democráticas, a estrutura política da Alemanha e da França, se via, em grande medida, influenciada pelo fato de que o Estado constituía a fonte de renda de uma fatia considerável do eleitorado. Não eram apenas as hordas de funcionários públicos, e dos funcionários nos ramos nacionalizados dos negócios (por exemplo, ferrovias, correios, telégrafos etelefonia), havia aqueles que recebiam o seguro desemprego e outros benefícios da seguridade social, bem como agricultores e alguns outros grupos que, direta ou indiretamente, o governo subsidiava. Seu maior interesse estava em obter mais para si dos fundos públicos. Não se importavam com questões de "ideais", tais como a liberdade, a justiça, a supremacia da lei ou um bom governo. Pediam mais dinheiro, só isso. Nenhum candidato ao parlamento, às dietas provinciais, ou às câmaras municipais podia correr o risco de se opor ao apetite dos funcionários públicos pelos aumentos. Os diversos partidos políticos competiam em sua avidez por superar uns aos outros em munificência.

No século XIX, os parlamentos pretendiam restringir tanto quanto possível os gastos públicos. Agora, no entanto, a frugalidade passou a ser algo desprezível. Gastos sem limites passaram ser encarados como uma política sensata. Tanto o partido no poder como a oposição se esforçavam para serem populares, utilizando sua generosidade. A criação de novas repartições com novos funcionários era vista como uma política "positiva", e todo esforço para evitar o desperdício de fundos públicos era desacreditado como "negativismo".

Se grande parte dos eleitores estiver na folha de pagamento do governo, não poderá subsistir a democracia representativa. Estará liquidada a democracia se os membros do parlamento já não se considerarem mandatários dos contribuintes, mas representantes daqueles que recebem salários, vencimentos, subsídios, auxílio desemprego e outros benefícios do tesouro.

É esta uma das antinomias inerentes às questões constitucionais atuais. Por sua causa, muitos perderam a esperança no futuro da democracia. À medida que se convenceram da inevitabilidade da tendência em direção a uma maior interferência do governo nos negócios, a mais repartições com mais funcionários, a mais auxílios e subsídios, não 
puderam deixar de perder sua confiança no governo pelo povo.

\section{IV - A Burocratização da Mente}

A moderna tendência à onipotência e ao totalitarismo do governo teria sido cortada pela raiz se seus defensores não tivessem logrado sucesso em doutrinar a juventude com os seus princípios e em impedi-la de se familiarizar com os ensinamentos da Economia.

A Economia é uma ciência teórica e, como tal, não impõe ao homem que valores preferir ou que objetivos mirar. Não estabelece metas finais. Esta não é a tarefa do homem que pensa, mas do homem que age. A ciência é fruto do pensamento, a ação é produto da vontade. Neste sentido, podemos dizer que a economia, como uma ciência, é neutra no que diz respeito aos objetivos finais do esforço humano.

Contudo, a situação é diferente no que diz respeito aos meios a serem utilizados para se atingirem determinados fins sociais. Neste aspecto, a economia é o único guia confiável para a ação. Se os homens anseiam por sucesso na busca de qualquer meta social, devem ajustar sua conduta aos resultados do pensamento econômico.

O fato mais marcante da história intelectual dos últimos cem anos é a luta contra a economia. Os defensores da onipotência do governo não entraram em uma discussão dos problemas envolvidos; ao contrário, insultaram os economistas, lançaram suspeitas sobre seus motivos, ridicularizaram-nos e lançaram maldições sobre eles.

No entanto, nossa tarefa não é analisar este fenômeno. Temos de nos limitar à descrição do papel que a burocracia vem desempenhando nele.

Na maioria dos países do continente europeu, as universidades são de propriedade do governo e por ele geridas. Estão sujeitas ao controle do Ministério da Educação, da mesma forma que uma delegacia de polícia está sujeita ao chefe do departamento de polícia. Os professores são funcionários públicos do mesmo modo que policiais e funcionários aduaneiros. O liberalismo do século XIX tentou limitar o direito de o Ministério da Educação interferir com a liberdade de professores universitários ensinarem o que consideravam verdadeiro e correto. Porém, na medida em que o governo é quem nomeava os professores, eram nomeados somente indivíduos confiáveis e leais, ou seja, aqueles que compartilhavam da perspectiva do governo e estavam dispostos a desacreditar a economia e a ensinar a doutrina da onipotência governamental.

Também nesta questão, como em todos os outros campos da burocratização, a Alemanha do século XIX estava muito à frente de outros países. Nada caracteriza melhor o espírito das universidades alemãs do que um trecho do discurso pronunciado pelo fisiologista Emil du Bois-Reymond (18181896), em 1870, em sua dupla capacidade de reitor da Universidade de Berlim e presidente da Academia Prussiana de Ciências: "Nós, a Universidade de Berlim, abrigados defronte ao Palácio Real, somos, pela carta de nossa fundação, o guarda-costas intelectual da Casa de Hohenzollern". Era inconcebível para a mente prussiana a ideia de que um fiel escudeiro da casa real professasse pontos de vista contrários aos princípios de seu empregador, o governo. Sustentar a teoria de que existem coisas tais como as leis da economia era entendido como uma espécie de rebelião. Pois, se existem leis econômicas, então os governos não podem ser vistos como onipotentes, uma vez que suas políticas só poderiam ter sucesso se conciliadas ao funcionamento dessas leis. Assim, a principal preocupação dos professores alemães de ciências sociais era denunciar a escandalosa heresia de que há uma regularidade nos fenômenos econômicos. Tornou-se um anátema o ensino da economia, e wirtschaftliche Staatswissenschaften (aspectos econômicos da ciência política) ocuparam seu lugar. As únicas qualidades exigidas de 
um professor universitário de ciências sociais eram um menosprezo pelo funcionamento do sistema de mercado e um entusiástico apoio ao controle governamental. Sob o Kaiser, os marxistas radicais que defendiam abertamente a insurreição revolucionária e a derrubada violenta do governo não eram nomeados para cátedras de tempo integral; a República de Weimar praticamente aboliu esta discriminação.

A economia trata do funcionamento de todo o sistema de cooperação social, com a interação de todos os seus determinantes e com a interdependência dos vários ramos da produção. Não pode ser dividida em campos separados passíveis de serem discutidos por especialistas que negligenciam todo o resto. É simplesmente absurdo analisar o dinheiro ou o trabalho ou o comércio exterior com o mesmo tipo de especialização que os historiadores adotam quando dividem a história humana em vários compartimentos. É possível abordar a história da Suécia sem praticamente referência alguma à história do Peru. Contudo, não se pode tratar dos salários sem, ao mesmo tempo, examinar os preços das mercadorias, as taxas de juros e o lucro. Toda alteração sofrida por um dos elementos econômicos afeta todos os demais elementos. Ninguém jamais definirá quais serão as consequências uma determinada política ou mudança se limitar sua investigação a um segmento individual do sistema como um todo.

É justamente esta interdependência que o governo não quer ver quando se intromete em assuntos econômicos. $\mathrm{O}$ governo finge ser dotado do poder místico de conceder favores advindos de uma inesgotável cornucópia de fartura. É onisciente e onipotente a um só tempo. Por meio de uma varinha mágica, é capaz de criar felicidade e abundância.

A verdade é que o governo não tem condições de dar se não tirar de alguém. Os subsídios nunca são financiados pelo governo com seus próprios recursos; é à custa do contribuinte que o Estado os concede. A inflação e a expansão do crédito, as atuais modalidades favoritas de generosidade governamental, nada acrescentam à quantidade de recursos disponíveis. Conferem prosperidade a alguns, mas apenas na medida em que fazem outros mais pobres. A interferência com o mercado, com os preços das mercadorias, salários e taxas de juros, conforme determinado pela oferta e pela procura, pode, no curto prazo, atingir os fins contemplados pelo governo. Mas, no longo prazo, essas medidas sempre resultarão em um estado de coisas que, do ponto de vista do governo, é mais insatisfatório do que a situação anterior que pretendiam modificar.

O governo não tem o poder de dar prosperidade a todos. Tem a possibilidade de elevar a renda dos agricultores por meio da redução coerciva da produção agrícola nacional. Todavia, os preços mais elevados dos produtos agrícolas são pagos pelos consumidores, não pelo Estado. A contrapartida do melhor padrão de vida dos agricultores é a redução do nível de vida do restante da nação. O governo é capaz de proteger as pequenas lojas contra a concorrência de lojas de departamentos e cadeias de lojas. Porém, aqui, mais uma vez, são os consumidores que pagam a conta. $\mathrm{O}$ Estado pode melhorar a situação de uma parte dos assalariados por meio de legislação supostamente pró-trabalho ou por dar rédeas à pressão e compulsão sindicais. No entanto, se essa política não resultar em um aumento correspondente nos preços dos fabricantes, o que elevaria novamente os salários reais ao nível de mercado, acarretará o desemprego de uma parcela considerável dos que estão dispostos a trabalhar por salários.

Um minucioso exame dessas políticas do ponto de vista da teoria econômica irá, necessariamente, demonstrar como são fúteis. É por isso que os burocratas fazem da economia um tabu. Os governos, por sua vez, incentivam os especialistas que limitam suas observações a um campo restrito, sem se preocupar com as consequências futuras de uma determinada política. O economista trabalhista leva em conta apenas os resultados imediatos das políticas pró- 
trabalhistas, o economista agrário somente a elevação dos preços agrícolas. Tanto um como o outro analisam os problemas apenas do ponto de vista dos grupos de pressão que são imediatamente favorecidos pela medida em pauta e negligenciam suas consequências sociais mais profundas. Não são economistas, mas intérpretes das atividades do governo em uma esfera específica da administração.

Desta forma, devido à interferência do governo nos negócios, a unidade das políticas governamentais há muito já se esfacelou em partes mal coordenadas. Longe vai a época em que ainda era possível falar da política de um governo. Hoje, na maioria dos países, cada ministério segue seu próprio caminho, trabalhando contra os esforços dos demais ministérios. O Ministério do Trabalho pretende manter mais altos os salários e mais baixo o custo de vida. Porém, o Ministério de Agricultura do mesmo governo visa a preços mais elevados dos alimentos, e o Ministério do Comércio tenta elevar, por meio de tarifas, os preços das mercadorias produzidas internamente. Um ministério luta contra o monopólio, enquanto outros estão ansiosos para propiciar - por meio de tarifas, patentes etc. - as condições necessárias para a construção da contenção monopolista. E cada ministério faz referência à opinião de especialistas em suas respectivas áreas.

Assim, os alunos deixam de ser expostos a uma iniciação à economia. Aprendem fatos incoerentes e desconexos a respeito de várias medidas governamentais que frustram umas às outras. Suas teses de doutorado e suas pesquisas de pós-graduação não tratam de economia, mas de vários temas da história da economia e de diversos casos de interferência do governo nos negócios. Esses estudos estatísticos detalhados e bem documentados sobre a situação do passado imediato (que, equivocadamente, muitas vezes se rotula de estudos sobre a situação "atual") são de grande valia para o futuro historiador. Não são menos importantes para o exercício da profissão de advogados e escriturários. Mas, certamente, não são capazes de compensar pela falta de instrução em economia. É incrível que a tese de doutorado de Gustav Stresemann (1878-1929) verse sobre as condições do comércio de cerveja engarrafada em Berlim. De acordo com as regras do currículo universitário alemão, isso significa que o autor dedicou substancial parcela de sua pesquisa universitária ao estudo da comercialização da cerveja e dos hábitos de seu consumo pela população. Este foi o equipamento intelectual que o glorificado sistema universitário alemão forneceu a um indivíduo que mais tarde atuou como chanceler do Reich nos anos mais críticos da história da Alemanha ${ }^{3}$.

Após a morte dos antigos professores que ascenderam a suas cátedras durante o curto florescimento do liberalismo alemão, tornou-se impossível ouvir qualquer coisa sobre economia nas universidades do Reich. Não havia mais economistas alemães, e não mais se encontravam os livros dos economistas estrangeiros nas bibliotecas universitárias. Os cientistas sociais não seguiram o exemplo dos professores de teologia que familiarizavam seus alunos com os princípios e dogmas de outras igrejas e seitas e com a filosofia do ateísmo, pois desejavam refutar os credos que consideravam heréticos. Tudo o que os estudantes das ciências sociais aprendiam com seus professores era que a economia é uma ciência espúria e que os chamados economistas são, como disse Karl Marx (1818-1883), apologistas servis dos injustos interesses de classe dos exploradores burgueses, prontos a vender o povo aos grandes negócios e ao capital financeiro ${ }^{4}$. Os formandos deixavam as universidades como defensores convictos do totalitarismo da variedade nazista ou da estirpe marxista.

As circunstâncias eram semelhantes em outros países. A mais eminente instituição edu-

\footnotetext{
${ }^{3}$ Nota original do editor norte-americano: Gustav Stresemann atuou como chanceler da Alemanha em 1923 e como ministro das relações exteriores entre 1923 e 1929.

4 Ver: POHLE, Ludwig. Die gegenwärtige Krisis in der deutschen Volkswirtschaftslehre: Betrachtungen über das Verhältnis zwischen Politik und nationalökonomischer Wissenschaft. Leipzig: Deichertsche Verlagsbuchhandlung, 2ª ed., 1921.
} 
cacional francesa era a École Normale Supérieure, em Paris; seus graduados preenchiam os mais importantes cargos da administração pública, da política e da educação superior. Esta escola era dominada pelos marxistas e outros partidários do controle completo pelo governo. $\mathrm{Na}$ Rússia, o Governo Imperial não admitia a uma cátedra universitária ninguém suspeito de nutrir as ideias liberais da economia "ocidental". Todavia, por outro lado, nomeou muitos representantes da ala "leal" do marxismo, ou seja, aqueles que se mantiveram fora do caminho dos fanáticos revolucionários. Assim, os próprios czares contribuíram para o posterior triunfo do marxismo.

O totalitarismo europeu é resultado da preeminência da burocracia no campo da educação. As universidades abriram caminho para os ditadores.

Hoje, tanto na Rússia como na Alemanha, as universidades são os principais baluartes do sistema de partido único. Não só as ciências sociais, história e filosofia, mas todos os outros ramos do conhecimento, da arte e da literatura são arregimentados ou, como dizem os nazistas, gleichgeschaltet (alinhados). Até mesmo Sidney Webb (1859-1949) e Beatrice Webb (1858-1943), apesar de ingênuos e acríticos admiradores dos soviéticos, ficaram chocados quando descobriram que o Journal for Marxist-Leninist Natural Sciences defende "o partido na matemática" e "a pureza da teoria marxista-leninista em cirurgia" e que o Soviet Herald of Venereology and Dermatology visa a examinar todos os problemas que discute do ponto de vista do materialismo dialético ${ }^{5}$.

\section{V - Quem Deve EstaR No Comando?}

Em qualquer sistema de divisão do trabalho, é necessário que haja um princípio

${ }^{5}$ WEBB, Sidney \& WEBB, Beatrice. Soviet Communism: A New Civilization? New York: C. Scribner's Sons, 1936. Vol. II, p. 1000. para a coordenação das atividades dos diversos especialistas. $\mathrm{O}$ esforço do especialista ficaria desprovido de sentido e seria contrário a seus propósitos se a supremacia do público não fosse para ele um fio condutor. Naturalmente, o fim único da produção é servir os consumidores.

Em uma sociedade de mercado, o princípio diretor é a motivação do lucro. Sob o controle do governo, é a arregimentação. Não há uma terceira possibilidade. Para aquele que não é motivado pelo impulso de ganhar dinheiro no mercado, é necessário haver um código que lhe diga o que fazer e como. Uma das objeções mais comuns levantadas contra o sistema liberal e democrático do capitalismo é que este dá particular ênfase aos direitos do indivíduo, negligenciando seus deveres. As pessoas se concentram em seus direitos e esquecem suas obrigações. No entanto, do ponto de vista social, os deveres dos cidadãos são mais importantes que seus direitos.

Não há necessidade de nos debruçarmos sobre o aspecto político e constitucional dessa crítica antidemocrática. Os direitos do homem, conforme codificados nas diversas declarações de direitos, são promulgados para a proteção do indivíduo contra a arbitrariedade dos governos. Se não fosse por essas declarações, todos os indivíduos seriam escravos de governantes despóticos.

$\mathrm{Na}$ esfera econômica, o direito de adquirir e de possuir bens não é um privilégio. E o princípio que melhor assegura a satisfação das necessidades dos consumidores. Aquele que anseia por conquistar, adquirir e possuir riquezas se vê diante da necessidade de servir aos consumidores. A motivação do lucro é a maneira de dar supremacia ao público. Quanto maior sucesso tiver um indivíduo no fornecimento aos consumidores, maiores serão seus ganhos. É vantajoso para todos que fique rico o empresário que produz bons sapatos pelo menor custo; a maioria das pessoas iria sofrer alguma perda se a lei limitasse seu direito que tem este empresário de ficar mais rico. Uma lei assim só favoreceria seus concorrentes menos 
eficientes. Não baixaria, mas, ao contrário, elevaria o preço dos sapatos.

O lucro é a recompensa para o cumprimento mais eficaz de alguns deveres voluntariamente assumidos. É o instrumento que dá supremacia às massas. O homem comum é o cliente para quem trabalham os capitães da indústria e todos os seus assessores.

Há contestações de que isso não é verdadeiro no que tange aos grandes negócios. O consumidor não tem escolha a não ser utilizar-se de determinada empresa ou renunciar à satisfação de uma necessidade vital. Assim, é forçado a se submeter a qualquer preço que venha a cobrar o empresário. Os grandes negócios já não são apenas fornecedores e abastecedores, mas assumem o controle. Não têm necessidade de melhorar ou baratear seu serviço.

Examinemos o caso de uma estrada de ferro que faz a conexão entre duas cidades que não estão ligadas por qualquer outra linha férrea. Podemos até mesmo ignorar o fato de que outros meios de transporte estejam em concorrência com a estrada de ferro: ônibus, automóveis de passageiros, aviões e embarcações fluviais.

Com base nestes pressupostos, é verdade que quem quiser viajar será obrigado a utilizar os serviços da ferrovia. No entanto, este fato não elimina o interesse da companhia em oferecer um serviço bom e barato. Nem todos os que pensam em se deslocar são obrigados a fazer a viagem, quaisquer que sejam as condições. O número dos que viajam, seja por prazer ou para negócios, depende da eficiência do serviço e dos preços cobrados. Algumas pessoas irão viajar de qualquer maneira. Outras irão viajar somente se a qualidade e a velocidade do serviço e os preços baixos tornarem atraente o ato de viajar. É exatamente este segundo grupo cuja freguesia significa para a empresa a diferença entre um faturamento modesto ou mesmo ruim e uma atividade lucrativa. Se esta análise é verdadeira para uma ferrovia com base nas hipóteses extremas aventadas acima, é muito mais verdadeira no que se refere a qualquer outro ramo de negócios.
Todos os especialistas, quer sejam empresários ou profissionais liberais, estão plenamente conscientes de sua dependência de diretrizes dos consumidores. A experiência quotidiana ensina-lhes que, sob o capitalismo, sua principal tarefa é servir aos consumidores. Os especialistas que não possuem um entendimento dos problemas sociais fundamentais se ressentem profundamente dessa "servidão" e querem ser libertados. A revolta de especialistas tacanhos é uma das poderosas forças que empurram na direção da burocratização geral.

$\mathrm{O}$ arquiteto deve ajustar seus projetos aos desejos daqueles para os quais constrói casas; ou - no caso de prédios de apartamentos - dos proprietários que querem possuir um edifício que se adapte aos gostos dos potenciais inquilinos e, portanto, possam ser alugados com facilidade. Não há necessidade de descobrir se o arquiteto está certo em acreditar que é ele quem sabe como deve ser uma bela casa e não os tolos leigos que não têm bom gosto. $\mathrm{O}$ arquiteto pode espumar de raiva quando é forçado a corromper seus magníficos projetos a fim de agradar a seus clientes: ele anseia por um estado ideal de coisas em que pudesse construir casas que atendessem a seus próprios padrões artísticos. Sonha com uma secretaria de habitação do governo e, em seus devaneios, vê a si mesmo no comando dessa repartição. Quando isso ocorrer, irá construir habitações de acordo com seus próprios padrões estéticos.

Este arquiteto ficaria muito ofendido se alguém viesseachamá-lodeaspiranteaditador. Meu único objetivo, poderia responder, é fazer as pessoas felizes, fornecendo-lhes casas melhores; as pessoas são ignorantes demais para saber o que melhor promoveria seu próprio bem-estar; o perito, sob os auspícios do governo, deve cuidar delas; deveria haver uma lei contra prédios feios. Perguntemos, no entanto, quem irá decidir qual tipo de estilo arquitetônico deve ser considerado bom e qual deve ser considerado ruim? Nosso arquiteto irá responder: eu, o especialista, é óbvio. Audaciosamente, desconsidera o fato 
de que há, mesmo entre os arquitetos, grande dissidência em relação aos estilos e valores artísticos.

Não queremos destacar o fato de que este arquiteto, mesmo sob uma ditadura burocrática, e em particular sob tal totalitarismo, não será livre para construir de acordo com suas próprias ideias. Será obrigado a acatar o gosto de seus superiores burocráticos, os quais estarão sujeitos aos caprichos do ditador supremo. Tampouco na Alemanha nazista os arquitetos tinham liberdade: deviam adequar-se aos planos de Hitler, um artista frustrado.

Há algo ainda mais importante. No campo da estética, bem como em todos os campos da atividade humana, não existem critérios absolutos do que é belo e o que não é. Se um indivíduo obriga seus concidadãos a se submeterem a seus próprios padrões de valor, não os tornará mais felizes. Pois são capazes de decidir sozinhos o que os faz felizes e o que apreciam. Não se aumenta a felicidade de alguém que deseja muito assistir a uma apresentação da comédia ligeira Abie's Irish Rose de Anne Nichols (1891-1966) forçando-o a assistir a uma perfeita apresentação do Hamlet de William Shakespeare (1564-1616) em seu lugar. Pode-se ridicularizar seu mau gosto, mas só o indivíduo detém a supremacia em matéria de sua própria satisfação.

O nutricionista ditatorial quer que seus concidadãos se alimentem de acordo com suas próprias ideias sobre a nutrição perfeita. Quer lidar com as pessoas como o criador de gado trata de suas vacas. Não percebe que a alimentação não é um fim em si mesma, mas um meio para se atingir outros fins. $\mathrm{O}$ fazendeiro não alimenta sua vaca a fim de fazê-la feliz, mas para atingir um objetivo que a vaca bem alimentada deve atender. Existem vários esquemas para a alimentação das vacas. Qual deles o fazendeiro seleciona depende se quer obter tanto leite quanto possível ou o máximo de carne, ou algo diferente. Todo ditador planeja criar, alimentar e treinar seus semelhantes da mesma maneira que o criador faz com seu gado. Seu objetivo não é fazer as pessoas felizes, mas conduzi-las a uma situação que faz feliz a ele, o ditador. Quer domesticá-las, dar-lhes o status de gado. $\mathrm{O}$ criador de gado também é um déspota benevolente.

A pergunta é: Quem deve estar no comando? Deve o homem ser livre para escolher seu próprio caminho em direção ao que acha que vai fazê-lo feliz? Ou deve um ditador usar seus semelhantes como peões em seus esforços para tornar mais feliz a si mesmo, o ditador?

Podemos admitir que alguns especialistas estejam certos ao nos dizerem que a maioria das pessoas se comporta de maneira tola em sua busca da felicidade. Entretanto, não se pode fazer um homem mais feliz simplesmente ao colocá-lo sob tutela. Decerto, os especialistas das diversas agências governamentais são excelentes homens. Todavia, não estão certos ao se indignarem sempre que o legislador frustra seus projetos cuidadosamente elaborados. De que vale um governo representativo, indagam: limita-se a frustrar nossas boas intenções. Mas a única pergunta é: quem deve governar o país? Os eleitores ou os burocratas?

Qualquer imbecil é capaz de utilizar um chicote e forçar outras pessoas a obedecerem. Porém, são necessárias inteligência e diligência para servir ao público. Apenas alguns têm sucesso na produção de sapatos melhores e mais baratos do que seus concorrentes. O especialista ineficiente irá sempre visar à supremacia burocrática, pois tem plena consciência do fato de que não poderá ter sucesso dentro de um sistema competitivo. Para ele, a burocratização generalizada constitui uma proteção. Equipado com o poder de um cargo, irá impor suas decisões com a ajuda da polícia.

Por trás de toda essa defesa fanática do planejamento e do socialismo, muitas vezes, nada mais há do que a consciência íntima da inferioridade e ineficiência próprias. $\mathrm{O}$ indivíduo que tem consciência de sua incapacidade de suportar a concorrência despreza "este sistema competitivo louco". Ele, que é inepto para servir a seus concidadãos, ambiciona governá-los. cos 